\title{
EFEKTIFITAS PEMBELAJARAN PRAKTIK BACA PUISI BAGI SISWA MELALUI SEJUMLAH FITUR APLIKASI DI ANDROID PADA SISTEM PEMBELAJARAN ONLINE
}

\author{
Mulziani* \\ E-mail : mulziani3305@student.unri.ac.id \\ *Program Studi Pendidikan Bahasa dan Sastra Indonesia, Universitas Riau
}

\section{Pengantar}

Maju dan berkembangnya suatu bangsa, dilihat dari seberapa besar kualitas dan peran generasinya berupaya memberikan sumbangsih dalam bentuk pikiran maupun tindakan nyata yang berdampak besar bagi perubahan bangsanya ke arah yang lebih baik. Pada dasarnya, seberapa besar kualitas seseorang dapat dinilai dari pola pikir dan perilakunya. Semakin tinggi pola pikir dan ilmu seseorang, maka akan semakin tinggi pula akhlak dan sikapnya. Semua itu dapat dibentuk melalui proses pendidikan dan pengajaran. Pendidikan merupakan suatu kegitan yang dilakukan untuk mengoptimalkan perkembangan potensi, kecakapan, dan karakteristik pribadi seseorang sekaligus menjadi bagian dalam proses perubahan sikapnya kearah yang lebih baik. Kegiatan pendidikan dilakukan untuk mencapai suatu tujuan tertentu. Menurut Sukardi (2003), tujuan pendidikan minimal diarahkan kepada pencapaian empat sasaran, yaitu 1) Pengembangan kepribadian peserta didik 2) Pengembangan kemampuan kemasyarakatan 3) Pengembangan kemampuan melanjutkan studi dan 4) Pengembangan kecakapan dan kesiapan untuk bekerja.

Berdasarkan hal tersebut, dapat diketahui bahwa peran pendidikan sangat berpengaruh besar dalam bidang apapun. Proses pendidikan tidak pernah luput dari proses belajar mengajar yang melibatkan peserta didik dan tenaga pendidik. Peran tenaga pendidik sangat menentukan jalannya proses belajar mengajar dan kualitas peserta didik sebagai bentuk representasi dari hasil belajar. Maka dari itu, seorang tenaga pendidik bertanggung jawab bagi peserta didik yang diajarnya 
dalam memberikan pengetahuan, nilai-nilai maupun norma-norma yang akan menjadi penuntun hidupnya. Semua proses dalam pendidikan ini diharapkan dapat terciptanya nilai-nilai baru dalam bagi kehidupan. Berdasarkan ketetapan Undangundang Guru dan Dosen (UU GD), setiap guru maupun dosen diharapkan memiliki empat kompetensi diri dalam mengajar. Kompetensi ini meliputi kompetensi pedagogik, kompetensi kepribadian, kompetensi sosial, dan kompetensi profesional. Empat kompetensi ini bersifat vital, karena dapat menentukan seberapa tinggi kualitas guru dan pendidikan disuatu instansi. Dalam hal ini, sangat jelas sekali bahwa seorang guru menjadi model utama bagi siswanya. Guru dituntut untuk lebih kreatif dan inofatif dalam mengajar agar siswa tertarik mengikuti kelas dan dapat memahami materi pembelajaran dengan baik.

Proses pembelajaran online yang dilakukan menyeluruh di semua jenjang pendidikan merupakan suatu kebiasaan baru yang harus dijalani. Banyak penyesuaian dan pembaruan turut dirasakan oleh guru dan peserta didik dalam pembelajaran online karena lebih banyak memanfaatkan peran teknologi.

Pembelajaran bahasa Indonesia bukan sekedar mata pelajaran yang bersifat teori semata, namun juga mengedepankan aspek kognitif, psikomor dan afektif yang dapat menambah wawasan dan juga keterampilan siswa. Salah satu materi yang sangat mengedepankan aspek-aspek tersebut adalah pembelajaran baca puisi. Pembelajaran ini bersifat praktik sebagai bentuk implementasi dari teori yang telah dipelajari. Menurut Endang (2015:54), dalam membaca puisi titik sentuhnya adalah membaca di depan umum. Sekalipun membaa teks pada saat baca puisi, pembeca puisi harus menampilkan puisinya dengan mimic, pantomimic dan teknik vocal. Artinya, titik fokus baca puisi hanyalah membaca bukan menghafal dengan memperhatikan kaidah yang berlaku. Berbeda dengan pandangan Atmazaki dan Hasanuddin W.S (1990), mendeskripsikan bahwa membaca puisi merupakan satu upaya dalam menyampaikan isi perasaan dan pikiran yang terkandung dalam puisi kepada orang lain supaya mereka dapat memahami dan mampu menikmati apa yang terkandung dalam puisi itu. Dalam proses pembacaan puisi, seseorang tidak akan pernah lepas dari yang namanya 
vokal, intonasi dan ekspresi sebagai pendukung penyampaian emosi dan pesan kepada orang lain. Hal ini sangat sejalan dengan pendapat Mohd. Harun (2018:196), bahwa ada beberapa hal yang harus diperhatikan oleh seorang pembaca puisi yakni (1) penafsiran (2) kesiapan mental (3) artikulasi, intonasi, irama, volume dan modulasi.

Berdasarkan penjabaran di atas diketahui bahwa banyak sekali ketentuan yang ada dalam pembelajaran baca puisi, sehingga pembelajaran baca puisi secara online pada masa pandemi tentunya memberikan sedikit kesulitan baik bagi guru maupun peserta didik. Dalam hal ini, sebagai pihak sentral, seorang guru dituntut memiliki kemampuan menguasai teknologi seperti komputer beserta media pendukung yang terdapat padanya, agar mampu menjawab arus tantangan zaman terutama dalam menciptakan inovasi pembelajaran bagi siswa.

Menurut Sarwiji Suwandi (2019:6), menjelaskan bahwa komputer dan internet dapat dijadikan sebagai sarana yang efektif bagi siswa untuk belajar, karena dapat menambah pengetahuan, dan meningkatkan keterampilan berbahasa. Hal ini menjadi penanda bahwa perkembangan teknologi yang semakin canggih dapat menjadi pendukung yang efektif dalam proses pembelajaran apabila dimanfaatkan dan digunakan secara tepat. Asis Sefuddin \& Ika Berdiati (2014:2), berpendapat bahwa seorang guru itu merupakan desainer, yang bertugas mendesain atau merancang pembelajaran sehingga apa yang disajikan menjadi efektif dan berterima oleh pembelajar, sedangkan siswa menjadi arsitek yang membangun pengetahuan dan wawasan mereka sendiri dalam proses belajar. Guru yang berperan sebagai desainer dalam pembelajaran dituntut untuk mampu merancang sekaligus memanajemeni pembelajaran dengan konsep yang matang sehingga pembelajaran yang berlangsung itu dinilai sebagai pembelajaran efektif dan berhasil.

Sampai saat ini, masih banyak dari kalangan generasi muda termasuk di dalamnya siswa, belum memanfaatkan fitur-fitur teknologi seperti berbagai aplikasi media sosioal dengan baik. Maka dari itu, peran guru dalam melihat permasalahan ini sangatlah diperlukan. Memanfaatkan berbagai fitur dari media sosial untuk pembelajaran merupakan satu bentuk inovasi yang baik, terlebih 
untuk pembelajaran yang bersifat praktik seperti baca puisi. Banyak sekali fiturfitur media sosial yang dapat dimanfaatkan guru sebagai sarana pendukung dalam pembelajaran praktik baca puisi seperti menggunakan berbagai fitur aplikasi media sosioal di android diantaranya seperti aplikasi YouTube, Instagram dan Facebook.

\section{Tindakan yang Dilakukan}

Dengan memanfaatkan sejumlah aplikasi media sosial diharapkan mampu menunjang pelaksanaan pembelajaran baca puisi yang bersifat praktik. Keterbatasan ruang dan waktu akibat pandemi, membuat guru harus lebih inovatif dalam mencari solusi agar tujuan pembelajaran yang telah ditetapkan dapat tercapai, berjalan maksimal dan menumbuhkan minat ataudan motivasi belajar siswa. Siswa yang memiliki sikap dan motivasi belajar yang tinggi dapat menimbulkan intensitas belajar yang lebih tinggi. Dengan kata lain, aktivitas belajar siswa dapat meningkat jika sikap dan motivasi belajarnya juga meningkat, (Zulhafizh, Atmazaki \& Syahrul R 2013:14).

Banyak sekali fitur media sosial yang dapat dimanfaatkan guru dalam pembelajaran baca puisi, sebagaimana berikut ini:

a. YouTube

Aplikasi YouTube memberikan banyak keuntungan bagi penggunanya, yaitu cukup dengan menggungah video yang bersifat positif, menarik, serta memberikan manfaat banyak kepada khalayak. Dengan demikian, video-video tersebut akan memiliki penggemarnya tersendiri yang diwujudkan dalam bentuk dukungan like dan subscribe. Semakin banyak artinya video kita dianggap menarik dan bermanfaat bagi penonton sehingga bukan tidak mungkin menjadi salah satu sumber finansial.

Menggunakan aplikasi YouTube sebagai sarana pembelajaran baca puisi lebih kepada hal yang bersifat video. Guru meminta peserta didik membuat video praktik baca puisi, kemudian mengunggahnya di YouTube. Selanjutnya, peserta didik mengirimkan link alamat YouTubenya agar nantinya guru dapat melakukan penilaian dengan 
leluasa, baik dari segi vokal, intonasi, ekspresi tanpa ada batasan waktu serta video tersebut tetap dapat diputar ulang kapan pun dan dimanapun.

b. Instagram

Berbeda dengan YouTube, Instagram memiliki banyak fitur yang dapat digunakan, delapan diantaranya adalah: (1) Feeds, yang digunakan sebagai tempat postingan akun pengguna (2) Instagram Story, merupakan fitur yang paling digemari para penggunanya karena dapat mengunggah apapun tanpa perlu memikirkan kerapian konten sebagaimana feeds (3) IGTV, IGTV juga dikenal dengan sebutan Instagram TV. Pengguna dapat menggungah video dengan durasi maksimal 10 menit.

Dalam pembelajaran baca puisi, isntagram dapat dimanfaatkan dengan maksimal sebagaimana halnya YouTube. Guru dapat meminta siswa menggunggah video pembacaan puisi di IGTV. Hal ini juga dapat menjadi pilihan siswa apabila ia memiliki kendala pada penggunaan aplikasi YouTube, maka dalam hal ini IGTV menjadi solusi yang sesuai dalam mengatasi hal tersebut.

c. Facebook

Grand Kennedy (2015:4), menjelaskan bahwa "It is a unanimous opinion that Facebook is the most popular social media platforms. There are more than 1.2 billion active users on Facebook. This the platform gives you the opportunity to advertise about various types the business can be paid or free advertising. It also gives you options create a page dedicated only to your business and this can help you get involved your potential customers. Facebook Ads work according to the PPC model which allows you to target specific ads and audiences. You can also share content and communicate with your audience on a personal level". Hal ini menandakan popularitas dan eksistensi Facebook tidak kalah saing dari segi jumlah penggunanya. Facebook menawarkan sejumlah fitur yang tidak hanya digunakan sebagai media berbalas pesan saja, tetapi facebook juga menjadi media iklan dan promosi terhadap suatu brand penjualan. Selain itu, facebook juga memiliki fitur posting foto dan video yang dapat 
dimanfaatkan sebagai sarana pembelajaran. Tidak jauh berbeda dengan Youtube dan Instagram, guru juga dapat memanfaatkan fitur ini sebagai tempat menggunggah video baca puisi oleh siswa.

Facebook merupakan salah satu aplikasi popular yang telah diluncurkan pada tahun 2004. Penggunaanya yang mudah, membuat aplikasi ini dapat digunakan oleh peserta didik secara leluasa terutama melalui pengawasan orang tua. Tidak sedikit jumlah peserta didik yang telah memilki akun pribadi di facebook. Maka dari itu, guru dapat memanfaatkan facebook sebagai salah satu media pembelajaran, yang tidak hanya sekedar memudahkan guru dalam melakukan penilaian karena dapat dilihat kapanpun dan dimanapun tanpa batsan waktu, melainkan agar siswa mendapatkan pengalaman baru untuk berani menampilkan bakatnya di depan umum secara tidak langsung. Video praktik baca puisi yang diunggah siswa di facebook secara tidak langsung merupakan bentuk apresiasi karya puisi hasil cipta para penyair hebat. Selain itu, juga menjadi sarana edukasi kepada banyak orang dan wujud cinta sastra dikalangan gerasi muda.

Untuk dapat menggunakan dan memanfaatkan berbagai fitur itu dengan baik, maka perlu kesiapan dari guru (khusus) dan peserta didik (umum). Karena menjadi guru tidak boleh hanya berlandaskan cinta dengan profesi guru saja, tetapi juga harus mengerti, menguasai, dan mampu mengimplementasi metodologi pembelajaran, Zulhafizh (2021:329). Berdasarkan hal ini, maka guru dituntut untuk lebih profesional, kreatif dan inovatif dalam mengajar terlebih dengan sistem pembelajaran online. Guru harus membuat berbagai inovasi yang dapat mendukung tercapainya tujuan pembelajaran dan pemahaman peserta didik terhadap mata pelajaran yang ia ampu dengan memanfaatkan peran teknologi. Untuk itu, ada beberapa hal yang harus dipersiapkan oleh guru dan siswa seperti:

1. Guru dan peserta didik harus mempersiapkan diri secar fisik dan mental dalam menjalani proses pembelajaran daring menggunakan sejumlah fitur 
aplikasi media sosial. Karena hal ini menjadi suatu yang baru saat media sosial yang biasanya digunakan sebagai interaksi sosial, kini juga dimanfaatkan dalam proses pembelajaran.

2. Guru terlebih dahulu harus memahami bagaimana penggunaan aplikasi YouTube, Instagram, Facebook yang baik dan benar untuk media pembelajaran agar nantinya dapat memberikan penjelasan yang tepat kepada peserta didik.

3. Guru menjelaskan dan memberikan contoh bagaimana sistem pembelajaran baca puisi dengan memanfaatkan sejumlah fitur media sosial yang akan dilaksanakan nantinya kepada peserta didik.

4. Membuka sesi tanya jawab yang dapat dilakukan pada ruang zoom meeting atau google meet sebagai usaha untuk melihat sejauh mana pemahaman siswa serta kendala yang mereka hadapi untuk dapat di atasi sedini mungkin.

5. Membuat tutorial cara menggungah video baca puisi di sejumlah fitur media sosial melalui YouTube, agar lebih leluasa dan valid ketika menjelaskan karena tidak ada batasan waktu sebagaimana saat menjelaskan pada ruang zoom meeting atau google meet. Tetapi, guru juga perlu melakukan peninjauan pemahaman siswa terhadap video tutorial yang dibuat melalui zoom meeting atau google meet.

\section{Sarana Pendukung}

Dalam proses belajar mengajar yang berlangsung secara online, perihal menguasai berbagai aplikasi menjadi syarat utama agar proses pembelajaran tetap berlangsung sehingga mau tidak mau mengharuskan para pendidik keluar dari zona nyaman dan harus mampu beradaptasi secepatnya dengan pembelajaran daring. Selain penguasaan aplikasi, hal yang tidak kalah penting adalah sarana pendukung yang harus dipersiapkan guru untuk peserta didik. Tidak lengkapnya sarana pendukung, membuat proses pembelajaran tidak efektif dan efisien karena semuanya dalam keadaan kekurangan. Hal ini dapat menyebabkan menurunnya semangat dan motivasi belajar siswa. 
Adapun sarana pendukung yang dapat digunakan dalam menunjuang keefektifan pembelajaran praktik baca puisi bagi siswa melalui sejumlah fitur aplikasi di android pada sistem pembelajaran online, adalah handphone android dan juga laptop, karena dua hal ini menjadi syarat utama dalam pelaksananaan pembelajaran secara daring. Guru dan siswa akan mengalami kesulitan untuk mengunduh layanan aplikasi seperti YouTube, Instagram dan Facebook yang akan digunakan sebagai media praktik baca puisi jika tidak memiliki handphone android dan juga laptop. Kehadiran handphone android dan juga laptop memberikan manfaat besar bagi manusia, alat itu dizaman sekarang bukan lagi sebagai suatu keperluan melainkan sebagai kebutuhan. Handphone android dan juga laptop juga digunakan untuk mengunduh aplikasi lain seperti Google Classroom, Google Meet, Zoom Meeting, Whattsaap dan Telegram yang digunakan sebagai media interaksi tatap muka secara virtual bagi guru dan siswa. Khususnya pada saat penyampaian materi, arahan dari guru serta kegiatan tanya jawab yang melibatkan peran guru dan siswa. Akan tetapi, semua aplikasi tersebut tidak akan berfungsi maksimal bila tidak ada kuota internet dan jaringan yang stabil. Penggunaan internet memungkinkan siswa untuk menemukan kenyamanan dan kemudahan, mereka dapat menemukan berbagai macam bantuan, tutorial dan jenis bahan bantuan lainnya yang dapat digunakan untuk meningkatkan pembelajaran mereka secara akademis (Raja \& Nagasubramani, 2018) dalam (Aryuna, D., R \& Mohammad, S., H, 2021:189). Maka dari itu, kuota internet dan jaringan yang stabil merupakan jantung kedua setelah handphone android dan juga laptop bagi guru dan siswa dalam proses pembelajaran.

Selanjutnya, website terkait materi baca puisi, video referensi dari Youtube atau video pembelajaran dari guru (mengenai matri baca puisi beserta praktiknya), buku paket/buku pegangan/e-book materi pembelajaran baca puisi, buku kumpulan puisi dari penulis terkenal (disiapkan oleh guru, dalam bentuk ebook atau pdf) merupakan satu kesatuan sebagai pendukung utama dalam pembelajaran daring. Semua bahan ajar tersebut harus dirancang oleh guru guru secara sistematis dan spesifik. Hal itu karena bahan ajar sebagai media dan 
metode pembelajaran yang sangat besar, artinya di dalam menambah dan meningkatkan efektivitas pembelajaran.

Saat siswa melakukan praktik baca puisi, ruangan yang baik dan luas serta kondusif saat melakukan perekaman video akan sangat menentukan seberana jernih suara yang dihasilkan. Ruangan yang menggema akan membuat suara terdengar lebih keras, dibandingkan di tempat yang terbuka karena adanya pengaruh suara lain seperti angin, suara kendaraan dan lain-lain. Pengambilan video yang baik juga menjadi faktor penentu dalam perekaman vide baca puisi. Video yang direkam terlalu dekat dan terlalu jauh dirasa kurang bagus karena subjek tidak terliat dengan jelas. Maka dari itu, siswa dapat menggunakan bantuan tripot yang berfungsi sebagai penyangga handphone. Setelah video selesai diambil, maka langkah selanjutnya siswa harus mengunggah video tersebut ke salah satu fitur media sosial yang telah ditentukan. Video yang diunggah akan tampak bagus bila dilakukan proses pengeditan terlebih dahulu. Proses pengeditan dapat dilakukan disejumlah aplikasi edit video yang dapat diunduh peserta didik pada layanan playstore. Terakhir, hal yang tak kalah penting adalah, akun pribadi yang harus dimiliki siswa pada aplikasi media sosial sebagai media pendukung dalam pembelajaran baca puisi.

\section{Tindakan Solutif}

Dalam pelaksanaan proses belajar mengajar, guru tidak dapat menduga secara pasti kendala-kendala yang akan terjadi, terlebih dalam pembelajaran daring. Hal itu karena kendala itu bisa saja dialami oleh guru, peserta didik atau keduanya dalam waktu bersamaan. Maka dari itu, guru dianjurkan untuk selalu siap dan siaga menghadapi hal tersebut dengan membuat solusi cadangan bila sewaktuwaktu ia menghadapi kendalam dalam proses pembelajaran. Bila hal ini tidak diantisipasi, maka dapat berdampak pada semangat dan motivasi siswa karena mereka akan menganggap kendala tersebut sebagai suatu hambatan dan pada akhirnya mereka tidak semangat berpartisipasi dalam pembelajaran.

Biasanya, aplikasi yang paling direkomendasikan kepada guru saat melakukan proses belajar mengajar secara daring adalah aplikasi zoom meeting dan google 
meet. Kedua aplikasi ini dapat menampung kapasitas peserta belajar dalam jumlah banyak. Sehingga sangat efektif dan efisien bagi guru ketika memberikan penjelasan materi atau arahan kepada peserta didik, karena pada aplikasi tersebut seluruh peserta belajar dapat saling merespon dan menanggapi saat itu juga dengan cara menghidupkan mic atau fitur rise hand sebagai kode ingin menanggapi sesuatu. Aplikasi ini mirip dengan aplikasi video call pada Whattsap. Kita dapat berinteraksi dengan orang lain secara tatap muka via daring. Hanya saja, kapasitas zoom meeting dan google meet dapat memuat peserta dalam panggilan dalam jumlah banyak. Selain itu, baik guru dan peserta didik dapat menampilkan materi atau bahan presentasi seperti PPT kepada peserta zoom meeting atau google meet. Akan tetapi, bila kondisi jaringan tidak stabil dan koneksi internet buruk, maka dua aplikasi itu tidak dapat berfungsi. Maka guru dapat mengambil tindakan untuk pindah diskusi secara tulisan melalui aplikasi Whattsap, telegram atau google classroom. Whattsap, telegram dan google classroom, tidak banyak memakan kuota internet sehingga tetap dapat digunakan bila sewaktu kuota sedang menipis dan juga jaringan yang tidak stabil.

Permasalahan lain juga dapat muncul ketika pelaksanaan praktik baca puisi dilakukan sebagai implementasi dari teroi yang sudah dipelajari. Hal ini terjadi, karena guru dan peserta didik tidak berada dalam ruang dan waktu yang sama akibat pandemi. Maka dari itu, guru membuat inovasi pembacaan puisi oleh siswa dilakukan melalui video saja yang kemudian akan dinilai oleh guru. Dalam hal ini, siswa terlebih dahulu harus merekam aktivitasnya saat membaca puisi. Jika memiliki keahlian, siswa dapat mengedit video tersebut agar lebih menarik dan siap untuk diunggah ke aplikasi Youtube, Isntagram atau Facebook. Akan tetapi, tidak jarang dari siswa akan mengalami kendala dalam proses pengunggahan video ke sejumlah aplikasi tersebut. Misalnya karena kuota internet yang tiba-tiba habis, jaringan yang tidak bersahabat sehingga video tidak mau terunggah. Untuk mengantisipasi hal ini, maka guru dapat mengarahkan siswa menggunggah videonya di aplikasi bawaan android yaitu google drive. Penggunaan aplikasi ini tidak sulit, siswa cukup masuk ke aplikasi tersebut lalu pilih video mana yang ingin disimpan di google drive, lalu klik unggah. Tidak butuh waktu lama, video 
akan tersimpan secara otomatis dan siswa hanya perlu meng-copy link video tersebut lalu mengirimnya ke email guru bidang studi. Pilihan lain selain menggunakan google drive, agar siswa tetap dapat mengunggah video ke YouTube ialah dengan mencari tempat yang memiliki sumber WiFi atau lebih mudahnya menggunakan jasa warnet.

Kendala berikutnya adalah, meskipun guru telah membuat video pembelajaran sebaik mungkin mengenai materi baca puisi beserta teknik pembacaan puisi, tidak bisa dipungkiri bahwa masih ada siswa yang belum memahami apa yang disampaikan guru dalam video. Hal ini terjadi, karena ada siswa yang cepat paham dengan hanya menyimak video penyampaian materi oleh guru dari video saja da nada pula ketogori siswa yang hanya akan paham bila materi itu disampaikan langsung oleh gurunya secara tatap muka meskipun bersifat daring. Maka, untuk mengantisipasi hal ini, guru dapat membuat forum bersama siswa di zoom meeting atau google meet membahas materi yang belum dipahami oleh siswa dengan menyertai penayangan video pembacaan puisi dari para juara dalam berbagai ajang perlombaan. Setelah itu, agar dapat mengetahui siswa sudah lebih paham atau belum, guru dapat meminta siswa menanggapi video tersebut baik dari segi penyampaiannya, intonasi dan lain-lain. Selain itu, hal yang tidak kalah penting guru juga harus melampirkan materi atau modul sebagai panduan siswa dalam belajar.

Bila guru dan siswa masih belum menguasai penggunaan sejumlah aplikasi untuk mendukung pembelajaran, maka guru dan siswa dapat berlatih dengan melihat dan memahani dari berbagai reverensi seperti tutorial di Youtube. Selain itu, bisa juga dengan memanfaatkan sitem tutor sebaya, dengan cara mencari dan meminta orang yang kita anggap lebih ahli untuk mengajari kita bagaimana cara menggunakan aplikasi-aplikasi tersebut dalam mendukung proses belajar.

\section{Simpulan}

Pembelajaran praktik baca puisi bagi siswa melalui sejumlah fitur aplikasi di android pada sistem pembelajaran online, merupakan salah satu bentuk inovasi yang dapat dilakukan guru sebagai penunjang dalam mencapai tujuan 
pembelajaran. Efektifitas pembelajaran dapat terlaksana bila (1) guru dan pesera didik saling bekerja sama dalam pelaksanaan proses belajar mengajar agar capaian pembelajaran dapat terealisasi (2) kelengkapan sarana dan prasarana, kuota internet, jaringan yang stabil bagi guru dan khususnya murid sangat menentukan seberapa lancar proses pembelajaran berlangsung sekaligus menjadi penentu tinggi atau rendahnya minat dan belajar mereka (3) peran orang tua dalam membimbing dan membersamai putra putrinya saat pembelajaran daring sangatlah diperlukan. Hal ini karena orang tua menjadi pengontrol utama saat anak belajar jauh dari pantauan guru. Peran orang tua juga menjadi penyemangat dan dorongan bagi siswa untuk belajar lebih giat. Terlebih dalam hal ini, pembelajaran khususnya pembelajaran baca puisi menggunakan sejumlah aplikasi online (media sosial) sebagai bentuk solusi agar siswa tetap dapat maksimal dalam melaksanakan kegiatan praktik baca puisi. Oleh karena itu, orang tua diharapkan terus mendampingi anak-anaknya agar mereka tidak melakukan hal yang menyimpang.

Pembelajaran praktik baca puisi bagi siswa melalui sejumlah fitur aplikasi di android pada sistem pembelajaran online, dinilai sangat efektif karena generasi muda saat ini termasuk siswa, sudah sangat tidak asing dengan aplikasi media sosial seperti YouTube, Instagram dan Facebook. Mereka bahkan berperan aktif sebagai pengguna sosial media tersebut. Dengan memanfaatkan media sosial sebagai wadah pembelajaran diharapkan proses pembelajaran lebih efektif dan dapat menimbulkan ketertarikan dan motivasi belajar yang tinggi. Semakin tinggi rasa ketertarikan dan motivasi dalam belajar bagi siswa, maka semakin besar pula peluang pemahaman dan tujuan pembelajaran tercapai.

\section{Referensi}

Saefuddin, A., \& Berdiati, I. (2014). Pembelajaran Efektif. Bandung: PT Remaja Rosdakarya.

Martuti, E., S. (2015). Pembelajaran Bahasa Jawa di Sekolah Dasar. Magetan: CV Ae Media Grafika. 
Atmazaki, \& Hasanuddin. (1990). Pembacaan Karya Susastra Sebagai Suatu Seni. Padang: Angkasa Raya.

Zulhafizh, Atmazaki., \& Syahrul R. (2013). Kontribusi Sikap dan Motivasi Belajar Siswa Terhadap Hasil Belajar Bahasa Indonesia. Jurnal Bahasa, Sastra dan Pembelajaran, 1(2), 13-26.

Zulhafizh, Z. (2021). Peran dan Mutu Pelaksanaan Pembelajaran oleh Guru di Satuan Pendidikan Tingkat Atas. Jurnal Kependidikan: Jurnal Hasil Penelitian dan Kajian Kepustakaan di Bidang Pendidikan, Pengajaran dan Pembelajaran, 7(2), 328-339. doi:https://doi.org/10.33394/jk.v7i2.3344.

Sukardi. (2013). Metodologi Penelitian Pendidikan: Kompetensi dan Praktiknya. : Bumi Aksara.

Harun, M. (2018). Pembelajaran Puisi. Banda Aceh: Syiah Kuala University Press.

Suwandi, S. (2019). Pendidikan Literasi. Bandung: Remaja Rosdakarya PT.

Rahayu, A. D., \& Haq, M, S. (). Sarana dan Prasarana dalam Mendukung Pembelajaran Daring pada Masa Pandemi Covid-19.

Kennedy, G,. (2015). Social Media: Master Social Media Marketing (Facebook, Twitter, YouTube, Instagram). 
*Data Penulis

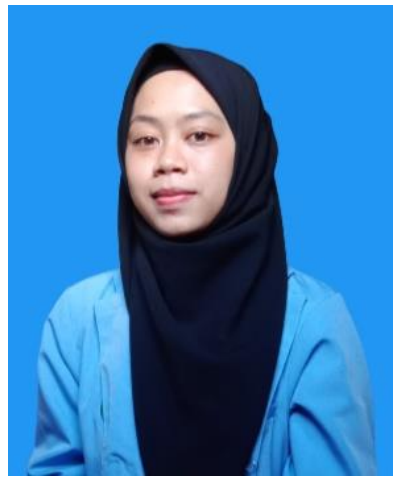

Mulziani, lahir di Selatpanjang, 11 Juli 2001. Pada tahun 2019 awal ia telah menyelesaikan pendidikan tingkat SMA/MA sederajat di MAN 1 Kepulauan Meranti. Pada tahun yang sama, beliau juga melanjutkan studi pada strata satu Jurusan Pendidikan Bahasa dan Seni di Program Studi Pendidikan Bahasa dan Sastra Indonesia FKIP Universitas Riau melalui jalur SBMPTN (Seleksi Bersama Masuk Perguruan Tinggi Negeri). Prestasi pertama yang diraihnya adalah perolehan juara 1 Voli Putri MAN CUP Selatpanjang tahun 2016. Kemudian disusul dengan perolehan Juara 1 Voli Putri MABA CUP FKIP UNRI tahun 2019. Selama menempuh pendidikan, sudah ada beberapa karya yang dihasilkan oleh Mulziani, meskipun masih sederhana dan jauh dari kata sempurna. Diantara karya itu adalah buku antologi cerpen yang berjudul Amor Et Spes edisi kelas menulis online yang ditaja oleh Komunitas Menulis Online Indonesia (KMO Indonesia) pada tahun 2020, buku antologi fabelous, buku antologi cerpen K(G)abut dan antologi cerpen 11 Maret 2019.

Kontak:

Hp/WA : : 082283155959

Email : mulziani3305@student.unri.ac.id 